\title{
Phosphatase activity and organic phosphorus turnover on a high Arctic glacier
}

\author{
M. Stibal, A. M. Anesio, C. J. D. Blues, and M. Tranter \\ Bristol Glaciology Centre, School of Geographical Sciences, University of Bristol, Bristol, BS8 1SS, UK \\ Received: 29 January 2009 - Published in Biogeosciences Discuss.: 27 February 2009 \\ Revised: 8 May 2009 - Accepted: 13 May 2009 - Published: 27 May 2009
}

\begin{abstract}
Arctic glacier surfaces harbour abundant microbial communities consisting mainly of heterotrophic and photoautotrophic bacteria. The microbes must cope with low concentrations of nutrients and with the fact that both the dissolved and debris-bound nutrient pools are dominated by organic phases. Here we provide evidence that phosphorus (P) is deficient in the supraglacial environment on a Svalbard glacier, we quantify the enzymatic activity of phosphatases in the system and we estimate the contribution of the microbes to the cycling of the dominant organic $\mathrm{P}$ in the supraglacial environment. Incubation of cryoconite debris revealed significant phosphatase activity in the samples (19-67 nmol MUP g $\mathrm{g}^{-1} \mathrm{~h}^{-1}$ ). It was inhibited by inorganic $\mathrm{P}$ during incubations and had its optimum at around $30^{\circ} \mathrm{C}$. The phosphatase activity measured at near-in situ temperature and substrate concentration suggests that the available dissolved organic $\mathrm{P}$ can be turned over by microbes within $\sim 3-11 \mathrm{~h}$ on the glacier surface. By contrast, the amount of potentially bioavailable debris-bound organic $\mathrm{P}$ is sufficient for a whole ablation season. However, it is apparent that some of this potentially bioavailable debris-bound $\mathrm{P}$ is not accessible to the microbes.
\end{abstract}

\section{Introduction}

Glacier surfaces, often referred to as supraglacial environments, are dominated by relatively simple, yet abundant and active, microbial communities which consist mainly of heterotrophic and photoautotrophic bacteria (Säwström et al., 2002; Kaštovská et al., 2005; Hodson et al., 2008; Anesio et al., 2009). The microbes are concentrated in cryoconite holes (Stibal et al., 2006), cylindrical water-filled depressions which form on glaciers when mostly wind-borne debris

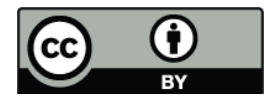

Correspondence to: M. Stibal (marek.stibal@bristol.ac.uk) deposited on the surface melts down into the ice (Wharton et al., 1985). The debris is, along with atmospheric aerosol deposition, the principal source of these organisms, as well as of the majority of nutrients. Arctic supraglacial environments are typically nutrient poor $(<4 \mu \mathrm{M}$ of dissolved inorganic $\mathrm{N},<0.1 \mu \mathrm{M}$ of soluble reactive $\mathrm{P}$ ), and the nutrients $(\mathrm{C}, \mathrm{N}, \mathrm{P})$ are present in mainly organic phases, as residue of microbial and/or plant cells and decayed organic matter (Stibal et al., 2008a,b). This suggests that inorganic nutrients are rapidly sequestered by microbial processes and that organic nutrients may too be recycled relatively rapidly.

It has been shown that Arctic supraglacial microbes are nutrient-limited in the aqueous phase (Säwström et al., 2007; Stibal and Tranter, 2007). Phosphorus (hereafter, P) is assumed to be the limiting nutrient due to the very low concentrations found in supraglacial waters, which are usually $<0.1 \mu \mathrm{M}$ (Mindl et al., 2007; Säwström et al., 2007; Stibal and Tranter, 2007). However, chemical and microbiological analysis of cryoconite debris and water has shown that the overwhelming majority of $\mathrm{P}$ on Arctic glaciers is bound to the debris, i.e. part of the chemical composition of the debris or adsorbed onto it (Säwström et al., 2002; Hodson et al., 2005; Stibal et al., 2008b), as are the microorganisms and their activity (Säwström et al., 2002; Hodson et al., 2007; Anesio et al., 2009). Thus, using only water samples and dissolved nutrient concentrations for assessing potential P limitation in this environment is clearly insufficient, and $\mathrm{P}$ cycling associated with the debris must also be considered. The first study to address nutrient limitation in the supraglacial environment in this more complex way examined the biogeochemical stoichiometry of both water and debris (Stibal et al., 2008b). A strong P deficiency in the aqueous phase was found, despite the presence of potentially bioavailable $P$ within the debris. This, together with the fact that the majority of $\mathrm{P}$ is present in the organic form, both in the transitory dissolved pool and the major debris-bound pool (Stibal et al., 2008b), poses the question whether the supraglacial microbes are in any way adapted to such conditions. 
Phosphatases are used by microbes to cleave the phosphate ion off complex P-containing organic molecules (phosphate monoesters in DOP) which are not readily bioavailable. Free phosphate can then be taken up into cells (Price and Morel, 1990). Production of phosphatase by microbes and its activity is therefore an efficient means of coping with, and may be an indication of, $\mathrm{P}$ deficiency in the environment (Cembella et al., 1984; Jansson et al., 1988). Phosphatase activity has been detected in microbial communities in various P-stressed environments, including the Antarctic Dry Valley ecosystem, namely in lake waters (Dore and Priscu, 2001; Lisle and Priscu, 2004), a subglacial discharge (Mikucki et al., 2004) and also in ice-lidded cryoconite holes (Foreman et al., 2007). The activity was found to be associated with bacteria within microbial aggregates in the Dry Valley lakes (Lisle and Priscu, 2004). However, no data on phosphatase activity from high Arctic environments are available to date.

Here we quantify and localise the phosphatase activity of the microbial community in cryoconite debris samples from Werenskioldbreen, a Svalbard glacier, using spectrofluorometry for bulk activity measurements, and epifluorescence microscopy for the localisation of the activity. We discuss the capacity of supraglacial microbes to use organic $\mathrm{P}$ as a source for their metabolic processes and the potential turnover rates of organic $\mathrm{P}$ in the supraglacial environment. This is of great significance for the whole Arctic terrestrial ecosystem, as the activity of supraglacial microbes and its limitations may have a considerable impact on carbon and nutrient cycling in the cryosphere (Hodson et al., 2005, 2008; Stibal et al., 2008a; Anesio et al., 2009).

\section{Study site}

Werenskioldbreen is a small polythermal-based valley glacier in southwest Spitsbergen, Svalbard $\left(77^{\circ} 04^{\prime} \mathrm{N}\right.$; $\left.15^{\circ} 15^{\prime} \mathrm{E}\right)$. The ablation or melt season during which liquid water is available takes place for several weeks to months in summer. The concentration of total dissolved phosphorus (TDP) in the surface waters on Werenskioldbreen is between 5.2 and $8.5 \mu \mathrm{g} \mathrm{l}^{-1}(\sim 0.17-0.28 \mu \mathrm{M})$, with DOP being a very important component ( $>80 \%$ of TDP; Stibal et al., 2008b). Cryoconite holes cover $\sim 1.5 \%$ of the surface of the ablation zone, with $\sim 12 \mathrm{~g}$ of debris per $\mathrm{m}^{2}$, and so Werenskioldbreen is estimated to contain over $200,000 \mathrm{~kg}$ of debris (Stibal et al., 2008a). The cryoconite debris contains $\sim 2.2 \mathrm{mg}$ of total $\mathrm{P}$ per g, and a significant part $(\sim 57 \%)$ of this debris bound $\mathrm{P}$ is organic, as determined by wet chemical sequential extraction. However, the amount of readily available P for microbes within the debris, defined as chloride and hydroxide extractable $\mathrm{P}$, is relatively small $\left(\sim 0.16 \mathrm{mg} \mathrm{g}^{-1}\right.$; Stibal et al., 2008b). The microbial community in cryoconite holes on Werenskioldbreen mainly consists of heterotrophic bacteria, photoautotrophic cyanobacteria and microalgae (Stibal et al., 2006; Stibal and Tranter, 2007).

\section{Methods}

\subsection{Sampling}

A bulked sample of cryoconite debris was collected from several holes on Werenskioldbreen on 3 September 2007. The holes were frozen solid at the time of sampling. The debris was removed from the holes with an ethanol-sterilised ice axe, placed into sterile $100 \mathrm{ml}$ HDPE bottles and frozen to $-20^{\circ} \mathrm{C}$. The samples were transported to the UK and stored in a freezer at $-20^{\circ} \mathrm{C}$ in the dark for 4 months until aliquots were melted for individual experiments. We expect that the microbes can cope with this means of storage reasonably well since they are exposed to freezing on a regular basis in winter ( $\sim 8$ months).

\subsection{Dissolved phosphorus analysis}

The initial concentrations of both inorganic and organic dissolved $\mathrm{P}$ in the experimental samples were determined in order to compare them with in situ values and to choose appropriate $\mathrm{P}$ additions for the enrichment experiments. Ten milligrams of debris was weighed into tubes, and $5 \mathrm{ml}$ of $5 \mathrm{mM}$ bicarbonate buffer $(\mathrm{pH}=8.2)$ was added. The tubes were then briefly vortexed, and the samples filtered through $0.2 \mu \mathrm{m}$ glass microfibre filters. Soluble reactive P (SRP) was determined spectrophotometrically at $880 \mathrm{~nm}$ in $1 \mathrm{~cm}$ disposable polycarbonate cells in a Shimadzu UV-Mini 1240 spectrophotometer (Shimadzu, Kyoto, Japan), using the standard molybdenum blue method (Murphy and Riley, 1962). The detection limit was $0.20 \mu \mathrm{M}$. Samples for TDP were acidified with potassium persulphate, autoclaved at $121^{\circ} \mathrm{C}$ and $15 \mathrm{psi}$ for $1 \mathrm{~h}$ (Jeffries et al., 1979), and analysed for SRP as above. DOP was calculated as the difference between TDP and SRP.

\subsection{Quantitative analysis of phosphatase activity}

The activity of phosphatase was quantified in the cryoconite samples from Werenskioldbreen using 4-methylumbelliferylphosphate (MUP) as a substrate analogue during controlled incubations. The hydrolysis product 4methylumbelliferone (MU) was analysed by spectrofluorometry.

Samples were incubated in acid-washed $15 \mathrm{ml}$ polypropylene centrifuge tubes. $10 \mathrm{mg}$ (wet weight) of freshly melted cryoconite debris was weighed into tubes, and $5 \mathrm{ml}$ of $5 \mathrm{mM}$ bicarbonate buffer $(\mathrm{pH}=8.2)$ was added, along with the desired amount of MUP (final concentration ranging from 0 to $500 \mu \mathrm{M}$ ). The tubes were then briefly vortexed, and incubated for up to $3 \mathrm{~h}$ either in the dark or at $50 \mu \mathrm{mol}$ photons $\mathrm{m}^{-2} \mathrm{~s}^{-1}$. This light intensity is lower than the average summer incident radiation on the glacier surface ( $\sim 250 \mu \mathrm{mol}$ photons $\mathrm{m}^{-2} \mathrm{~s}^{-1}$; Stibal et al., 2007), 
but had been shown sufficient for isolation and growth of a range of cryoconite photoautotrophs (A. M. Anesio, unpublished data). Eight incubation temperatures ranging from 0 to $40^{\circ} \mathrm{C}$ were used in order to assess the optimum temperature for the enzyme. Denatured blanks were prepared by boiling the samples for $10 \mathrm{~min}$ and cooling prior to MUP addition. Blanks containing no MUP were also incubated in order to evaluate background fluorescence of the debris and potential liberation of interfering compounds over the course of incubations. All the samples were centrifuged at $1000 \mathrm{rpm}$ for $1 \mathrm{~min}$ immediately before analysis. Blanks containing only bicarbonate buffer and MUP were prepared and measured in order to assess the fluorescence of spontaneously hydrolysed MUP, which was then subtracted from the samples fluorescence. Approximately $0.03-0.05 \%$ of MUP hydrolysed immediately after being added to samples, independent of the concentration (linear between 0.01$100 \mu \mathrm{M}$ MUP, $R^{2}>0.99$ ).

The samples were analysed with a SPEX Fluorolog-3 spectrofluorometer (Horiba Jobin Yvon, Edison, NJ, USA) with a xenon lamp. The excitation wavelength was set to $365 \mathrm{~nm}$ and the emission was detected at $450 \mathrm{~nm}$. Phosphatase activity was expressed as nmol of MU accumulated per gram of debris per hour using emission coefficients obtained from calibrations (0.001-0.5 $\left.\mu \mathrm{MMU} ; R^{2}>0.99\right)$. Individual samples were corrected for quenching according to the time elapsed from the addition of MUP to the measurement. This was usually $<5 \%$ as tested with MU standards. The MU accumulation was considered equivalent to MUP dephosphorylation.

The effect of the debris on the fluorescence performance was tested prior to experiments. When using near-in situ debris $(\mathrm{g})$ :water $(\mathrm{ml})$ ratios of $1: 5$ and $1: 50,>90 \%$ and $40-50 \%$ of the added MU, respectively, was adsorbed onto debris particles and thus lost from solution and undetectable. The ratio of 1:500 (i.e. $10 \mathrm{mg}$ in $5 \mathrm{ml}$ ) was found to sequester only 5$7 \%$ of $\mathrm{MU}$, with the background fluorescence of the debris being negligible (equivalent to $<1 \mathrm{nMMU}$ ), and so was used in the experiments. We acknowledge that this is a departure from the in situ conditions; however, we assume that the dilution affects the detectability of phosphatase activity much more than it does the activity itself.

Selected samples were enriched with inorganic $\mathrm{P}$ in the form of $\mathrm{KH}_{2} \mathrm{PO}_{4}$ in order to test the effect of readily available $\mathrm{P}$ on phosphatase activity. The $\mathrm{P}$ additions were from 0.3 to $10 \mu \mathrm{M}$. The immediate effect of $\mathrm{P}$ addition was tested by incubating the samples with MUP immediately after the enrichment for $30 \mathrm{~min}$ in the dark. The long-term effect was tested by incubating the samples for $24 \mathrm{~h}$ at the elevated $\mathrm{P}$ concentrations, followed by adding MUP and incubating for $30 \mathrm{~min}$.

The phosphatase activity was assumed to follow Michaelis-Menten kinetics, and the parameters $K_{m}$ (the Michaelis constant; the substrate concentration at which the reaction rate reaches half of its maximum value) and
$V_{\max }$ (the maximum rate of the reaction) were estimated using the Eadie-Hofstee equation, a linearised form of the Michaelis-Menten model,

$$
V=V_{\max }-K_{m} \frac{V}{[S]}
$$

where $V$ is the reaction rate $\left(\mathrm{nmol} \mathrm{g}^{-1} \mathrm{~h}^{-1}\right)$ and $[S]$ is the substrate concentration $(\mu \mathrm{M})$. The reaction rate, $V$, was measured at ten substrate concentrations ranging from 0.01 to $500 \mu \mathrm{M}$ with eight replicates per assay.

\subsection{Phosphatase activity visualisation and localisation}

Enzyme-labelled fluorescence (ELF) was used to localise the activity of phosphatase within the cryoconite debris. Cryoconite debris samples were stained either with ELF-97 only or counterstained with the DNA stain SYBR Gold, and then observed using epifluorescence microscopy in order to determine the total microbial abundance and the localisation of phosphatase activity sites. Chlorophyll autofluorescence was used to show whether photoautotrophic microorganisms were associated with phosphatase activity.

Samples were incubated in a similar manner as those for bulk activity measurements. Ten milligrams (wet weight) of freshly melted cryoconite debris was weighed into acid-washed $15 \mathrm{ml}$ polypropylene centrifuge tubes, and $4.75 \mathrm{ml}$ of deionised water was added. The tubes were incubated for $30 \mathrm{~min}$ at $5^{\circ} \mathrm{C}$, either in the dark or at $50 \mu \mathrm{mol}$ photons $\mathrm{m}^{-2} \mathrm{~s}^{-1}$, and the samples were then fixed by adding $250 \mu 1$ of formaldehyde (final concentration $1.9 \%$ ). One millilitre of the sample was then transferred to a clean $2 \mathrm{ml}$ Eppendorf tube. Blanks containing no debris were also incubated in order to evaluate potential contamination during handling.

ELF-97 (solution A, ELF-97 Endogenous Phosphatase Detection Kit E6601, Invitrogen, Eugene, OR, USA) was diluted 20 times with the detection buffer (solution B) and $100 \mu 1$ was added to the Eppendorf tube. The samples were stained for $15 \mathrm{~min}$ in the dark and filtered onto a $0.2 \mu \mathrm{m}$ Anodisc filter (Whatman, Maidstone, UK). Dried filters were then placed onto $100 \mu \mathrm{l}$ drops of SYBR Gold (Invitrogen, Eugene, OR, USA) for $15 \mathrm{~min}$, dried and mounted on microscopic slides with anti-fade agent (solution C).

The number of SYBR Gold stained cells was enumerated in 20 randomly selected fields with an Olympus BX41 epifluorescence microscope (Olympus Optical, Tokyo, Japan) using the filter block U-N31001 (excitation $480 \mathrm{~nm}$, emission $535 \mathrm{~nm}$; Chroma Technology, Rockingham, VT, USA). The presence and localisation of yellow-green fluorescing ELF alcohol precipitate was recorded using the filter block U-MWU2 (excitation 330-385 nm, emission 420+; Olympus Optical, Tokyo, Japan). Each precipitate was counted as one site of activity. Cells showing red chlorophyll autofluorescence were also enumerated using this filter 
Table 1. Abundance of all microbial and chlorophyll-containing (Chl+) cells, and the number of phosphatase activity (P-ase) sites and their association with microbial cells within cryoconite debris from Werenskioldbreen (mean $\pm \mathrm{sd}, \mathrm{n}=60$ ). No statistical differences between dark and light incubations were found ( $p>0.05$, t-test for independent samples).

\begin{tabular}{lcccc}
\hline incubation & $\begin{array}{c}\text { total cells } \\
\left(10^{4} \mathrm{mg}^{-1}\right)\end{array}$ & $\begin{array}{c}\text { Chl+ cells } \\
\left(10^{4} \mathrm{mg}^{-1}\right)\end{array}$ & $\begin{array}{c}\text { P-ase sites } \\
\left(10^{4} \mathrm{mg}^{-1}\right)\end{array}$ & $\begin{array}{c}\text { cell associated P-ase sites } \\
(\% \text { total sites })\end{array}$ \\
\hline dark & $42 \pm 26$ & $1.8 \pm 2.6$ & $5.7 \pm 3.8$ & $16 \pm 28$ \\
light & $44 \pm 28$ & $2.0 \pm 2.8$ & $5.2 \pm 5.4$ & $19 \pm 21$ \\
average & $43 \pm 27$ & $1.9 \pm 2.7$ & $5.5 \pm 4.7$ & $17 \pm 24$ \\
\hline
\end{tabular}

block. Ten experimental and two blank filters were enumerated, and the average blank counts were then subtracted from the experimental samples.

\section{Results}

The initial concentrations of soluble reactive phosphorus (SRP) and DOP in the experimental samples were $0.31 \pm 0.05 \mu \mathrm{M}$ (mean \pm sd) and $1.8 \pm 0.07 \mu \mathrm{M}$, respectively. DOP accounted for $82 \pm 2.9 \%$ of total dissolved $\mathrm{P}$ in the samples. The microbial abundance in the experimental samples was $\sim 4.3 \times 10^{8}$ cells per gram of debris and approximately $4 \%$ of the cells were chlorophyll-containing photoautotrophs (Table 1), mostly filamentous cyanobacteria from the group Oscillatoriales. Low numbers of eukaryotic green algae were also found.

The accumulation of MU in the samples over the course of incubations with MUP is shown in Fig. 1a. The temporal variation in the rate of the process, calculated from the amount of MU and the time of incubation, is shown in Fig. 1b. The rate varied between 19-67 nmol of MUP dephosphorylated per gram of cryoconite debris per hour. A peak $\left(\sim 40-67 \mathrm{nmol} \mathrm{MUP} \mathrm{g}^{-1} \mathrm{~h}^{-1}\right)$ was reached between 30-45 min after the beginning of all incubations, with a decline afterwards to $\sim 20 \mathrm{nmol} \mathrm{MUP} \mathrm{g}{ }^{-1} \mathrm{~h}^{-1}$. The denatured samples showed no significant accumulation of MU over time (Fig. 1a). Figure 2 shows the substrate response curve for phosphatase in the samples. The calculated maximum rate for the reaction, $V_{\max }$, was $77 \pm 2.6 \mathrm{nmol} \mathrm{MUP} \mathrm{g}{ }^{-1} \mathrm{~h}^{-1}$, and $K_{m}$, the substrate concentration at which $V=\frac{1}{2} V_{\max }$, was $13 \pm 1.2 \mu \mathrm{M}$.

Addition of inorganic $\mathrm{P}$ in the form of $\mathrm{KH}_{2} \mathrm{PO}_{4}$ had an immediate and significantly negative effect on phosphatase activity during incubations with the substrate (MUP) concentration close to the ambient value $(0.5 \mu \mathrm{M})$. The phosphatase activity in non-enriched samples was between 5.8 and $11 \mathrm{nmol} \mathrm{MUP} \mathrm{g}^{-1} \mathrm{~h}^{-1}$, and decreased with increasing concentration of SRP to $1.7-3.1 \mathrm{nmol} \mathrm{MUP} \mathrm{g} \mathrm{g}^{-1} \mathrm{~h}^{-1}$ in samples enriched with $10 \mu \mathrm{MP}$ (Fig. 3a). By contrast, no immediate effect was evident at the saturating concentration of MUP. Here, the phosphatase activity was

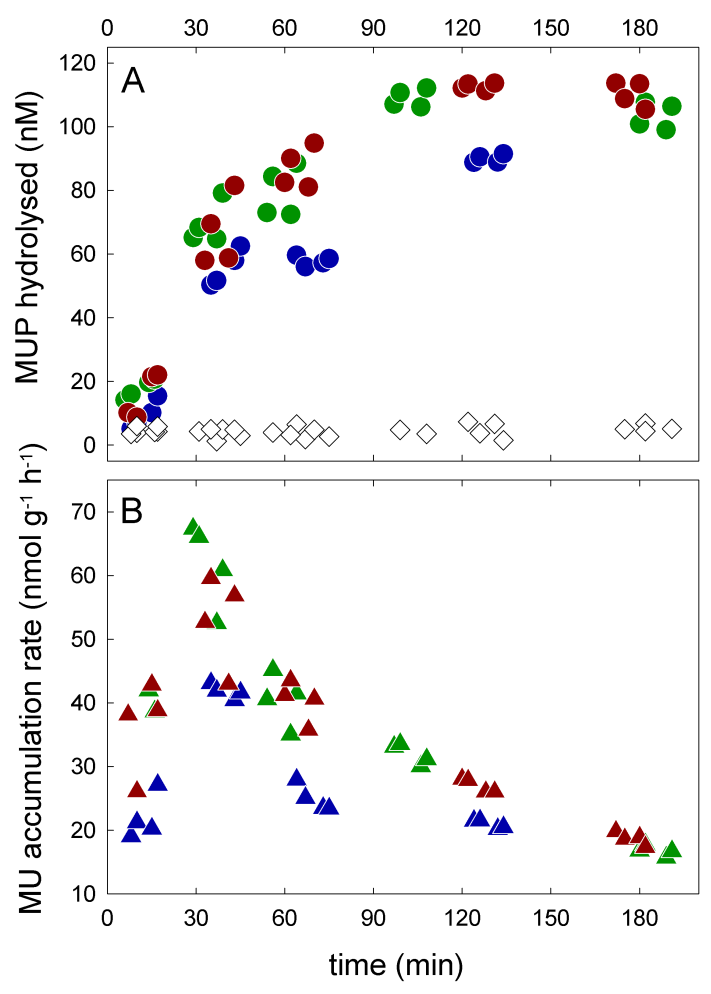

Fig. 1. Phosphatase activity in cryoconite samples from Werenskioldbreen. The initial substrate (MUP) concentration was $100 \mu \mathrm{M}$ and saturating. The samples were incubated in the dark at $5^{\circ} \mathrm{C}$. A. Dephosphorylation of MUP during incubation. Circles denote experimental samples, each colour represents one independent incubation. Diamonds are samples denatured by $10 \mathrm{~min}$ boiling. B. Rates of MU accumulation calculated from data in A.

between 47 and $73 \mathrm{nmol} \mathrm{MUP} \mathrm{g}{ }^{-1} \mathrm{~h}^{-1}$, with no significant difference between the samples (Fig. 3a).

Figure $3 b$ shows the effect of $\mathrm{P}$ addition after 24-h incubations. There was a significant decrease in phosphatase activity in the most enriched $(+10 \mu \mathrm{MP})$ samples (to $36 \pm 3.4 \mathrm{nmol} \mathrm{MUP} \mathrm{g}^{-1} \mathrm{~h}^{-1}$ ) when exposed to the saturating substrate concentration in the dark, whereas smaller $\mathrm{P}$ additions had no significant effect $\left(43 \pm 6.7 \mathrm{nmol} \mathrm{MUP} \mathrm{g}^{-1} \mathrm{~h}^{-1}\right.$ in non-enriched samples). No significant differences between 


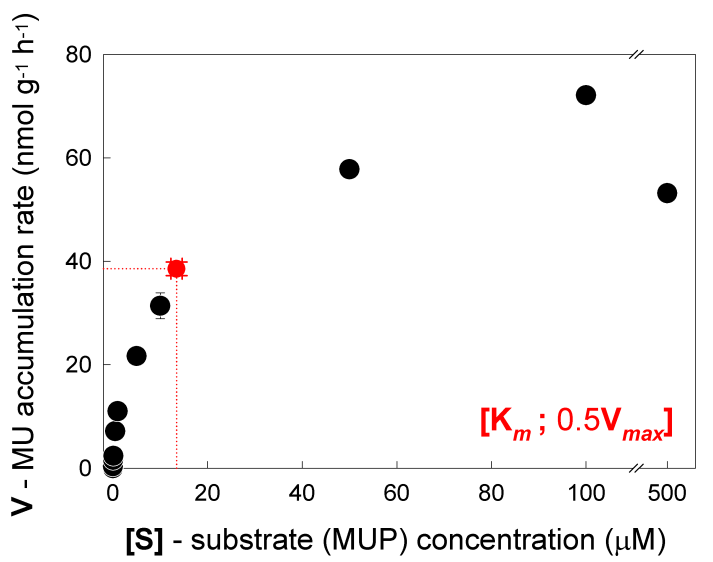

Fig. 2. Substrate response curve for phosphatase in cryoconite samples from Werenskioldbreen (mean $\pm \mathrm{sd}, \mathrm{n}=8$ ). The red circle denotes the point $\left[K_{m} ; \frac{1}{2} V_{\max }\right]$ calculated from Eadie-Hofstee linearisation of the Michaelis-Menten kinetics model (mean $\pm s d, n=8$ ). The samples were incubated at $5^{\circ} \mathrm{C}$ in the dark for $30 \mathrm{~min}$.

samples with different $\mathrm{P}$ additions were found for the illuminated samples, and the rates were between 14-45 $(28 \pm 6.3) \mathrm{nmol} \mathrm{MUP} \mathrm{g}^{-1} \mathrm{~h}^{-1}$. A significant negative effect of $\mathrm{P}$ addition in both dark and illuminated samples was observed at the near-in situ concentration, despite the great variability in phosphatase activity between samples (Fig. 3b). The rates of MUP dephosphorylation were significantly higher in samples that underwent a short incubation than in same-treatment samples pre-incubated for $24 \mathrm{~h}(p<0.01, \mathrm{t}$ test for dependent samples).

The phosphatase activity was significantly higher in the dark samples $\left(43 \pm 6.1 \mathrm{nmol} \mathrm{MUP} \mathrm{g}^{-1} \mathrm{~h}^{-1}\right.$ at $100 \mu \mathrm{MMUP}$, $1.5 \pm 0.9 \mathrm{nmol} \mathrm{MUP} \mathrm{g}^{-1} \mathrm{~h}^{-1}$ at $\left.0.5 \mu \mathrm{MMUP}\right)$ than in the illuminated ones $\left(28 \pm 6.3 \mathrm{nmol} \mathrm{MUP} \mathrm{g} \mathrm{g}^{-1} \mathrm{~h}^{-1}\right.$ at 100 $\mu \mathrm{M}$ MUP, $\quad 1.2 \pm 0.8 \mathrm{nmol} \mathrm{MUP} \mathrm{g}{ }^{-1} \mathrm{~h}^{-1}$ at $0.5 \mu \mathrm{MMUP}$ ), independent of the substrate concentration (Fig. 3b). Figure 4 shows the temperature response of phosphatase activity in the samples. The activity increased with increasing temperature and reached its maximum at $\sim 30^{\circ} \mathrm{C} \quad\left(210 \pm 2.3 \mathrm{nmol} \mathrm{MUP} \mathrm{g}^{-1} \mathrm{~h}^{-1}\right.$ at $100 \mu \mathrm{MMUP}$, $130 \pm 46 \mathrm{nmol} \mathrm{MUP} \mathrm{g}^{-1} \mathrm{~h}^{-1}$ at $0.5 \mu \mathrm{M}$ MUP), and steeply declined at higher temperatures.

Table 1 shows the numbers of phosphatase activity sites in the samples. The presence of phosphatase activity sites, both free and cell-associated, was often bound to the surface of debris particles (Fig. 5a-f). Large clusters of phosphatase activity sites were also observed in breaking eukaryotic cells. Most sites ( $>80 \%$ ) were free, and were not associated with any DNA-stained cells. Approximately $17 \%$ of the sites were associated with microbial cells. Figure $5 \mathrm{~g}$ shows a red-autofluorescing cyanobacterial filament with some phosphatase activity sites attached. In such cases it was not possible to unambiguously determine whether the phosphatase was produced by the photoautotroph or by heterotrophic cells

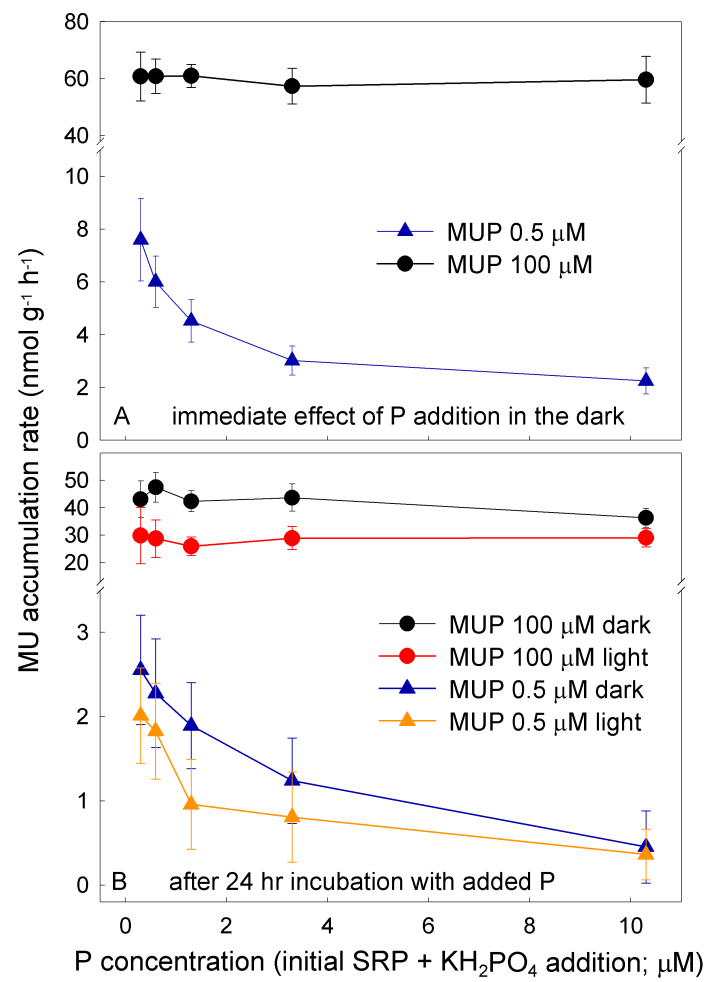

Fig. 3. Effect of $P$ addition on the phosphatase activity rate in cryoconite samples from Werenskioldbreen at saturating $(100 \mu \mathrm{M})$ and near-in situ $(0.5 \mu \mathrm{M})$ concentrations of the substrate. A. Immediate effect of $\mathrm{P}$ addition (mean $\pm \mathrm{sd}, \mathrm{n}=12$ ). B. Long-term effect of $\mathrm{P}$ addition (mean $\pm \mathrm{sd}, \mathrm{n}=8$ ). All samples were incubated at $5^{\circ} \mathrm{C}$.

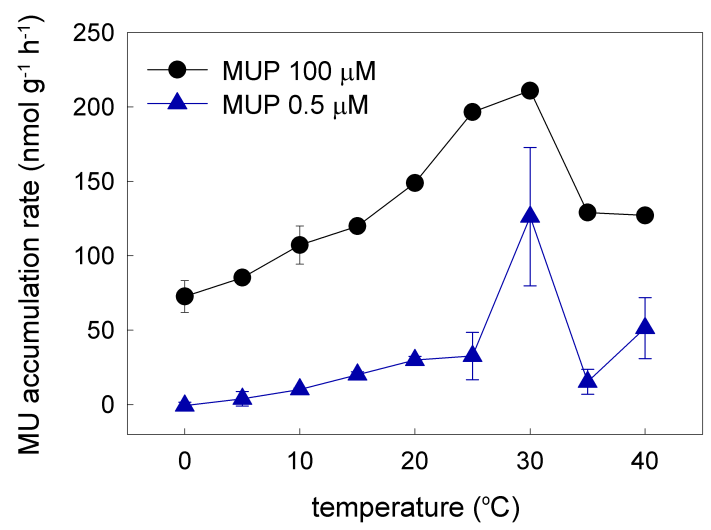

Fig. 4. Temperature response of phosphatase activity in cryoconite samples from Werenskioldbreen at saturating $(100 \mu \mathrm{M})$ and near-in situ $(0.5 \mu \mathrm{M})$ concentrations of the substrate (mean $\pm \mathrm{sd}, \mathrm{n}=6)$. The samples were incubated with the substrate in the dark for $30 \mathrm{~min}$.

adhered to the filament sheath. No significant difference in the numbers and distribution of phosphatase activity sites was found between illuminated samples and samples incubated in the dark. 

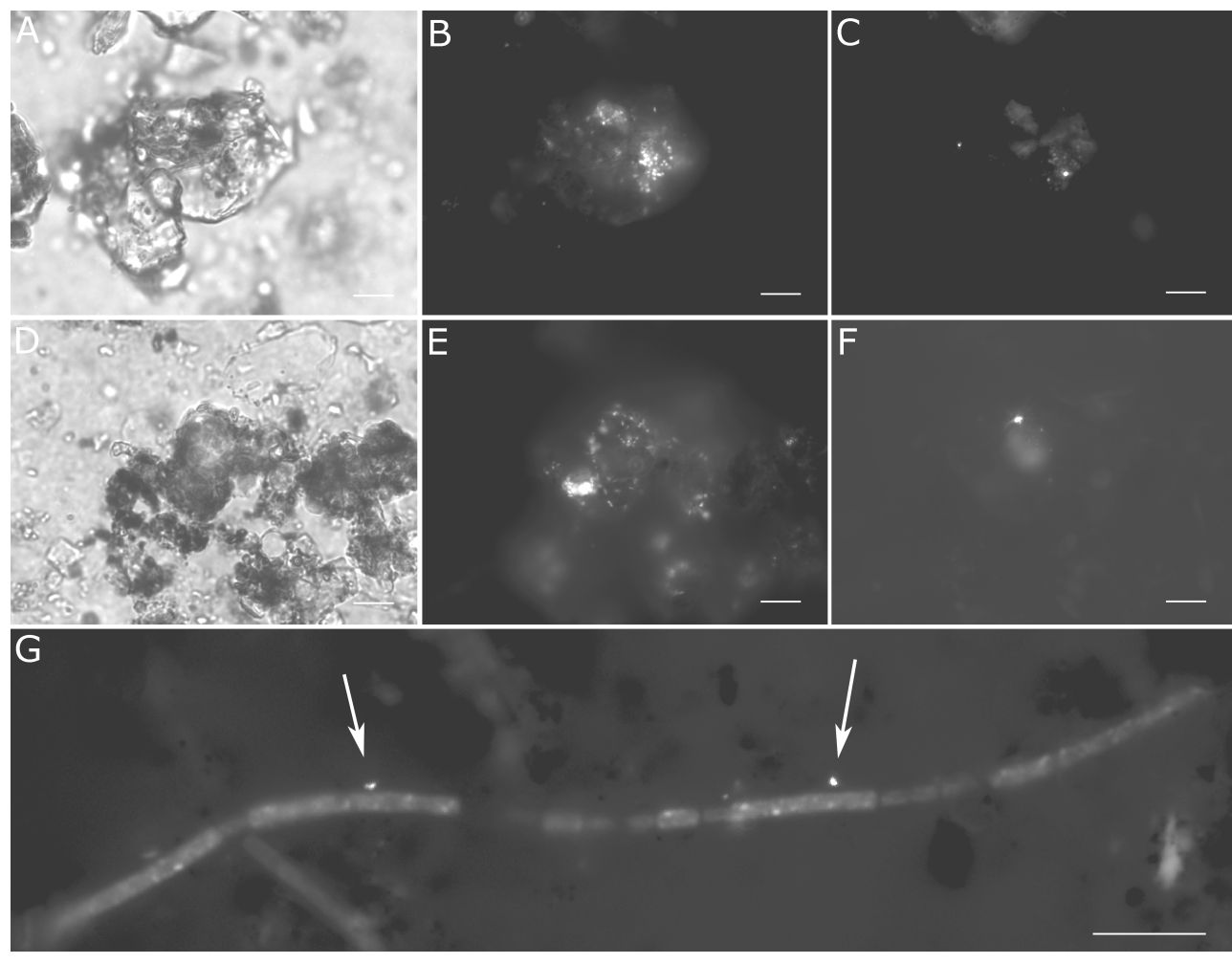

Fig. 5. Visualisation of phosphatase activity in cryoconite debris from Werenskioldbreen. A-C and D-F represent two fields of view. A, D. Light microscopy image of a cryoconite particle. B, E. Bacterial cells with SYBR Gold-stained DNA. C, F. Phosphatase activity sites as localised by ELF alcohol precipitate. G. A cyanobacterial filament visualised by chlorophyll autofluorescence with attached phosphatase activity sites (arrows). Scale bars in all images are $10 \mu \mathrm{m}$.

\section{Discussion}

\subsection{P deficiency in the supraglacial environment}

Significant phosphatase activity was detected in cryoconite debris samples from the surface of Werenskioldbreen, which indicates that the microbes within the debris are in some way P-stressed (Cembella et al., 1984; Price and Morel, 1990; Dyhrman and Palenik, 1999). This is further supported by two findings. First, the decrease in phosphatase activity after inorganic P additions (Fig. 3a, b) is considered to be a sign of P deficiency (Cembella et al., 1984). However, this may also be caused by direct inhibition of the enzyme by the added phosphate (Jansson et al., 1988), and will be further discussed below. Second, when the phosphatase activity is related to active microbial biomass $(\sim 0.1-0.2 \mathrm{mg}$ POM per gram of debris; Stibal et al., 2008a), the obtained values of $\sim 95-670 \mathrm{nmol} \mathrm{P} \mathrm{mg}(\mathrm{POM})^{-1} \mathrm{~h}^{-1}$ indicate severe $\mathrm{P}$ limitation (Pettersson, 1980; Jansson et al., 1988). Since this was determined at the near-in situ substrate concentration $(0.5 \mu \mathrm{M})$, we argue that $\mathrm{P}$ is deficient in the supraglacial environment of Werenskioldbreen. Other factors, such as the very high total dissolved nutrient (TDN:TDP) ratios found in cryoconite waters ( 60:1; Stibal and Tranter, 2007; Stibal et al., 2008b), also support this notion. Wet chemical sequential extraction suggests that there is likely to be sufficient potential bioavailable $\mathrm{P}$ within the debris for the microbial need (Stibal et al., 2008b). Our results may indicate that a proportion of this potentially bioavailable debris-bound $\mathrm{P}$ is not accessible to some cells, and hence that crude wet chemical sequential extraction may overestimate potentially bioavailable $\mathrm{P}$.

In this study, we determined phosphatase activity in cryoconite holes on a mass basis (i.e., nmol g ${ }^{-1} h^{-1}$ ). The reason why we relate the activity to the debris mass is that virtually all microbial cells and their activity in cryoconite holes are associated with the debris (Hodson et al., 2007). Nevertheless, in order to compare our results with other data, we converted our values from $\mathrm{nmol} \mathrm{g}^{-1} \mathrm{~h}^{-1}$ to the widely used nmol $1^{-1} h^{-1}$. We did this by using a conversion factor of 2 , since the debris:water ratio used in our experiments is equivalent to $2 \mathrm{~g}$ per litre. Our converted phosphatase activity at $5^{\circ} \mathrm{C}$ is $\sim 38-130 \mathrm{nmol}^{-1} \mathrm{~h}^{-1}$ and the calculated maximum rate $V_{\max }$ is $\sim 150 \mathrm{nmoll}^{-1} \mathrm{~h}^{-1}$. However, in the absence of information about the debris:water ratio in other studies, caution must be exercised when comparing these data with 
ours. The comparison is further complicated by the fact that we could not use the natural debris:water ratio in our experiments due to the technical problems described above, and the fact that the SRP and DOP concentrations in the experimental samples were $\sim 10$ times higher than those in situ. This was a result of a stable water column, shaking the tubes and using a high $\mathrm{pH}$ buffer, as opposed to flowing dilute supraglacial melt with a pH of $\sim 5.4$ in the field (Stibal et al., 2008a). However, the SRP:DOP ratio in the experimental samples was consistent with the in situ one (Stibal et al., 2008b).

The only previously reported phosphatase activity data from the glacial ecosystem come from the microbial communities of Taylor Valley in Antarctica. Phosphatase activity was determined in samples from cryoconite holes and the overlying ice from several glaciers, with recorded rates of $\sim 20 \mathrm{nmoll}^{-1} \mathrm{~h}^{-1}$ in cryoconite holes and $<5 \mathrm{nmoll}^{-1} \mathrm{~h}^{-1}$ in the overlying ice (Foreman et al., 2007). Mikucki et al. (2004) measured phosphatase activity in a subglacial discharge from Taylor Glacier. The rates were up to $\sim 20 \mathrm{nmoll}^{-1} \mathrm{~h}^{-1}$ in the ice melt and up to $\sim 60 \mathrm{nmoll}^{-1} \mathrm{~h}^{-1}$ in the slush ice slurry (Mikucki et al., 2004). A more detailed study on phosphatase activity and P deficiency was conducted in the permanently ice-covered lakes in Taylor Valley (Dore and Priscu, 2001). The results of the phosphatase activity measurements showed similar rates, up to $50 \mathrm{nmoll}^{-1} \mathrm{~h}^{-1}$, with the Michaelis constant $K_{m}$ between 2.4-3.8 $\mu \mathrm{M}$ and the maximum rate $V_{\max } \sim 50 \mathrm{nmol}^{-1} \mathrm{~h}^{-1}$.

The measured phosphatase activity and the calculated $V_{\max }$ in our Arctic samples are $\sim 2-6$ times higher than those measured in Antarctic cryoconite holes (Foreman et al., 2007) and up to $\sim 2.5$ higher than those in the Dry Valley lakes (Dore and Priscu, 2001). Our $K_{m}(13 \mu \mathrm{M})$ is also higher ( $\sim 3-5$ times) than that for the Antarctic lake community (Dore and Priscu, 2001). This may imply a lower affinity of the enzyme for the substrate in our samples, and thus less P-stressful conditions compared with those in Taylor Valley lakes (Jansson et al., 1988; Dore and Priscu, 2001). Although the SRP concentrations are similar within cryoconite holes on Werenskioldbreen and the Taylor Valley lakes $(0.75$ and $0.62 \mu \mathrm{gl}^{-1}$, respectively), the DIN:SRP ratios are mostly higher in the Antarctic lakes (50-3700) than in the Svalbard cryoconite holes ( 200) (Dore and Priscu, 2001; Stibal et al., $2008 \mathrm{~b}$ ). The lake water also lacks the P-rich debris which is present in cryoconite holes on Werenskioldbreen. This is consistent with cryoconite holes on Werenskioldbreen being less P-stressed than the Taylor Valley lakes.

\subsection{Environmental effects on phosphatase activity}

The time course of phosphatase activity and the accumulation of the product shown in Fig. 1a, b has a number of implications. First, no or very little active enzyme is likely to be preserved in cryoconite holes when they are frozen solid. This is indicated by the very low initial activity and product concentrations, and it is in contrast with the high time-zero activity determined in Antarctic lakes (Dore and Priscu, 2001). Second, the cryoconite microbial community reacts upon the $\mathrm{P}$ deficiency in the environment immediately after melting by producing phosphatase. The phosphatase activity was reduced after $\sim 30-45 \mathrm{~min}$ in our experiments (Fig. 1b). This may be explained by the inhibition of phosphatase caused by the product itself or by the occupation of active sites of the enzyme by the substrate (Cembella et al., 1984). Other negative factors, such as carbon and/or nitrogen limitation, may have played a role during the incubations and thus reduced the phosphatase activity. The negative effect of inorganic $\mathrm{P}$ on the phosphatase activity (Fig. 3) can be explained in two ways. First, the production of phosphatases by the microbes may be repressible and controlled by the ambient inorganic $\mathrm{P}$ concentration. Second, the phosphatase activity may be directly inhibited by phosphate itself (Cembella et al., 1984; Jansson et al., 1988). The latter suggestion is supported by the lack of inhibitory effect of inorganic $\mathrm{P}$ addition observed when the substrate concentration $(100 \mu \mathrm{M})$ was considerably higher than the concentration of added phosphate. It is also consistent with the fact that most phosphatase activity sites were found to be free and not associated with microbial cells, since the activity of free sites cannot be controlled via the production pathway. Therefore, it is possible that most phosphatase in our samples was produced constitutively by the cells, independent of the environment. Maintenance of high levels of phosphatase at very low substrate concentrations was found in the Dry Valley lakes and may be an adaptation to rapid and stochastic substrate input (Dore and Priscu, 2001). This may be applicable to Arctic cryoconite environments where the actual substrate concentration is probably dependent on the supraglacial water flow rate and residence time and the water:debris ratio in the hole (Stibal et al., 2008a,b).

The lower phosphatase activity determined in samples preincubated for $24 \mathrm{~h}$ (Fig. 3a, b) may be explained by dissolution of debris and/or initial microbial phosphatase activity after melting and consequent release of SRP into solution, with a subsequent inhibitory effect on phosphatase activity. This may be analogous to a low ablation period on the glacier surface, when the water residence time in cryoconite holes is relatively long (Stibal et al., 2008a).

The temperature effect on phosphatase activity shown in Fig. 4 agrees well with previous studies from other freshwater environments (Healey and Hendzel, 1979; Jansson et al., 1988), including Antarctic lakes (Dore and Priscu, 2001), with an optimum at $\sim 30^{\circ} \mathrm{C}$. This means that the microbes on the glacier surface, or at least their phosphatases, are not adapted to very low temperatures, and that their potential to utilise DOP is higher and may be used when they are transported into a higher-temperature downstream environment. This finding also supports the assertion that most microbes on glaciers are not indigenous and probably originate from nearby soil and freshwater ecosystems (Stibal and Tranter, 2007; Stibal et al., 2008a). 
Table 2. Organic $\mathrm{P}$ utilisation potential as calculated from phosphatase activity rates in non-enriched samples shown in Figs. 3 and 4. The differences in rates in same-type incubations between saturating and low substrate concentrations are significant $(p<0.01 ; \mathrm{t}$-test for dependent samples). The potential OP utilisation rates from the low near-in situ substrate concentrations were used for the OP turnover estimate.

\begin{tabular}{lccccc}
\hline incubation & substrate & $\begin{array}{c}\text { total OP } \\
(\mu \mathrm{M})\end{array}$ & $\begin{array}{c}\text { MUP } \\
(\% \text { total OP })\end{array}$ & $\begin{array}{c}\text { P-ase activity } \\
\left(\mathrm{nmol} \mathrm{MUP} \mathrm{g}^{-1} \mathrm{~h}^{-1}\right)\end{array}$ & $\begin{array}{c}\text { potential OP use } \\
\left(\mathrm{nmol} \mathrm{OP} \mathrm{g}^{-1} \mathrm{~h}^{-1}\right)\end{array}$ \\
\hline $\begin{array}{l}\text { short/dark } \\
\text { long/dark }\end{array}$ & saturating & \multirow{2}{*}{102} & \multirow{2}{*}{9} & $61 \pm 8.5$ & $62 \pm 8.7$ \\
long/light & & & & $43 \pm 6.7$ & $44 \pm 6.8$ \\
short/dark & & & & $30 \pm 10$ & $31 \pm 10$ \\
long/dark & \multirow{2}{*}{ low } & 2.3 & 22 & $7.6 \pm 1.6$ & $35 \pm 7.3$ \\
long/light & & & & $2.6 \pm 0.65$ & $12 \pm 3.0$ \\
\hline
\end{tabular}

\subsection{Distribution and association of phosphatase activity with microbial cells}

The higher phosphatase activity in the dark (Fig. 3b), or, rather, the lack of light stimulation on the activity, suggested that most of the activity may be associated with heterotrophic microbes. Therefore, we used enzyme-labelled fluorescence (ELF) in order to gain an insight into the distribution of phosphatase activity within the cryoconite community. ELF had been used for direct localisation of phosphatase activity and its association with different functional groups or species of microorganisms in various environments, including a mesotrophic mountain lake (Nedoma et al., 2003) and cyanobacteria-dominated oligotrophic wetland benthic mats (Sirová et al., 2006), where phosphatase activity was mostly unassociated with photoautotrophs. Lisle and Priscu (2004) also found the activity of phosphatase to be mostly associated with bacteria within microbial aggregates in the Dry Valley lakes. Our observations suggest that most phosphatase activity $(\sim 80 \%)$ in the supraglacial environment of Werenskioldbreen is not directly associated with microbial cells. Hence, it is not possible to distinguish between the heterotrophic and autotrophic contribution with confidence. The free phosphatase is probably supplied by excretion from growing bacteria and/or algae, as is often the case in lakes (Jansson et al., 1988). This also means that the free phosphatase and the products of its activity may be available for all the microbes, and that there is no competitive advantage with either heterotrophs or photoautotrophs regarding $\mathrm{P}$ availability.

The role of intracellular phosphatases that may be liberated from dead cells is not very clear. However, as intracellular phosphatases usually become inactive if they are released from the cell and exposed to the surrounding environment (Jansson et al., 1988), we assume that they are less important than extracellular phosphatases produced specifically to cope with environmental $\mathrm{P}$ stress.

\subsection{Potential DOP turnover}

In order to estimate the organic $\mathrm{P}$ turnover in situ we use the phosphatase activity measured at conditions simulating the supraglacial environment as close as possible. We use a nearin situ substrate concentration $(0.5 \mu \mathrm{M})$ and a low temperature $\left(5^{\circ} \mathrm{C}\right)$. We acknowledge the limitations of the laboratory approach, since we could not use the natural debris:water ratio and the $\mathrm{pH}$ and $\mathrm{P}$ concentration in the incubations were higher than those in the field. This may cause an overestimation of the organic P utilisation potential in the field. However, it is also important to realise that MUP represents only a part of all substrate available for phosphatase (i.e., DOP) in the experiments, and so the actual rates of DOP hydrolysis may be higher than the numbers shown in Figs. 3 and 4. Table 2 shows the actual rates calculated using the measured DOP concentration and the MUP additions. The difference between 0.5 and $100 \mu \mathrm{M}$ MUP is still statistically significant. Therefore, we consider the respective adjusted phosphatase rates $\left(9-35 \mathrm{nmol} \mathrm{OP} \mathrm{g}^{-1} \mathrm{~h}^{-1}\right.$; equivalent to $\sim 18$ $70 \mathrm{nmol}$ of DOP per litre per hour; Table 2) a reasonable approximation of the in situ DOP utilisation potential (Jansson et al., 1988). The lower values $\left(\sim 9 \mathrm{nmol} \mathrm{OP} \mathrm{g}^{-1} \mathrm{~h}^{-1}\right.$ or $\sim 18 \mathrm{nmol} \mathrm{DOP}^{-1} \mathrm{~h}^{-1}$ ) are probably more realistic because of the negative effect of the in situ temperature and $\mathrm{pH}$ and the lower concentration of substrate.

We estimate that the microbial community in cryoconite holes on Werenskioldbreen could turn over the present dissolved organic $\mathrm{P}$ in $\sim 2.9-11 \mathrm{~h}$, based on our estimated phosphatase activity of $18-70 \mathrm{nmol}$ of DOP per litre per hour and the in situ DOP concentration of $\sim 0.2 \mu \mathrm{M}$ (Stibal et al., 2008b). This is slower than in the Taylor Valley lakes, where the potential DOP turnover is less than $1 \mathrm{~h}$ (Dore and Priscu, 2001). However, as most microbes in Arctic cryoconite holes are attached to the debris (Säwström et al., 2002; Hodson et al., 2007; Anesio et al., 2009), it is likely that some organic $\mathrm{P}$ used by microbial phosphatases will be derived from the debris. The cryoconite debris on Werenskioldbreen 
contains $\sim 1.2 \mathrm{mg}$ of OP per gram (Stibal et al., 2008b), i.e. $\sim 39 \mu \mathrm{mol} \mathrm{g}^{-1}$. Based on the measured phosphatase activity of 9-35 nmol OP g ${ }^{-1} \mathrm{~h}^{-1}$, we estimate that the debris-bound OP could be turned over in $\sim 1100-4300$ h or $\sim 46-180$ days. This means that the organic phosphorus reservoir within the debris may supply $\mathrm{P}$ for the whole community over the entire ablation season. However, as discussed above, it is possible that some of the potentially bioavailable organic $\mathrm{P}$ in the debris is not accessible to some of the microbes, given the crude means of determination of this parameter by wet chemical sequential extraction.

\section{Conclusions}

The supraglacial microbes live in a P-deficient environment. Inorganic $\mathrm{P}$ is scarce and likely to be rapidly depleted. The microbes respond to this stress by producing and excreting phosphatases, and thus are able to recycle organic $\mathrm{P}$ liberated from dead cells and from organic matter which is brought to the glacier surface on a regular basis. However, the quality of the imported organic matter and the efficiency of its utilisation by the supraglacial microbes remains unknown and needs to be addressed in future research.

Acknowledgements. This research was supported by BIOTRACS, an EU-funded EST fellowship (MEST-CT-2004-514262) for MS, and NERC grants NE/D007321/1 and NE/G00496X/1 for AMA. We thank Stanislav Řehák and Josef Řehák Jr. for field assistance. Three anonymous reviewers are thanked for their insightful comments which greatly improved the manuscript.

Edited by: T. J. Battin

\section{References}

Anesio, A. M., Hodson, A. J., Fritz, A., Psenner, R., and Sattler, B.: High microbial activity on glaciers: importance to the global carbon cycle, Global Change Biol., 15, 955-960, 2009.

Cembella, A. D., Antia, N. J., and Harrison, P. J.: The utilization of inorganic and organic phosphorus compounds as nutrients by eukaryotic microalgae: A multidisciplinary perspective, Part 1., CRC Crit. Rev. Microbiol., 10, 317-391, 1984.

Dore, J. E. and Priscu, J. C.: Phytoplankton phosphorus deficiency and alkaline phosphatase activity in the McMurdo Dry Valley lakes, Antarctica, Limnol. Oceanogr., 46, 1331-1346, 2001.

Dyhrman, S. T. and Palenik, B.: Phosphate stress in cultures and field populations of the dinoflagellate Prorocentrum minimum detected by a single-cell alkaline phosphatase assay, Appl. Environ. Microbiol., 65, 3205-3212, 1999.

Foreman, C. M., Sattler, B., Mikucki, J. A., Porazinska, D. L., and Priscu, J. C.: Metabolic activity and diversity of cryoconites in the Taylor Valley, Antarctica, J. Geophys. Res., 112, G04S32, doi:10.1029/2006JG000358, 2007.
Healey, F. P. and Hendzel, L. L.: Fluorometric measurement of alkaline phosphatase activity in algae, Freshwater Biol., 9, 429-439, 1979.

Hodson, A. J., Mumford, P. N., Kohler, J., and Wynn, P. M.: The High Arctic glacial ecosystem: new insights from nutrient budgets, Biogeochemistry, 72, 233-256, 2005.

Hodson, A., Anesio, A. M., Ng, F., Watson, R., Quirk, J., IrvineFynn, T., Dye, A., Clark, C., McCloy, P., Kohler, J., and Sattler, B.: A glacier respires: quantifying the distribution and respiration $\mathrm{CO}_{2}$ flux of cryoconite across an entire Arctic supraglacial ecosystem, J. Geophys. Res., 112, G04S36, doi:10.1029/2007JG000452, 2007.

Hodson, A., Anesio, A. M., Tranter, M., Fountain, A. G., Osborn, M., Priscu, J., Laybourn-Parry, J., and Sattler, B.: Glacial ecosystems, Ecol. Monogr., 78, 41-67, 2008.

Jansson, M., Olsson, H., and Pettersson, K.: Phosphatases: origin, characteristics and function in lakes, Hydrobiologia, 170, 157 175,1988

Jeffries, D. S., Dieken, F. P., and Jones, D. E.: Performance of the autoclave digestion method for total phosphorus analysis, Water Res., 13, 275-279, 1979.

Kaštovská, K., Elster, J., Stibal, M., and Šantrůčková, H.: Microbial assemblages in soil microbial succession after glacial retreat in Svalbard (High Arctic), Microb. Ecol., 50, 396-407, 2005.

Lisle, J. T. and Priscu, J. C.: The occurrence of lysogenic bacteria and microbial aggregates in the lakes of the McMurdo Dry Valleys, Antarctica, Microb. Ecol., 47, 427-439, 2004.

Mikucki, J. A., Foreman, C. M., Sattler, B., Lyons, W. B., and Priscu, J. C.: Geomicrobiology of Blood Falls: an iron-rich saline discharge at the terminus of the Taylor Glacier, Antarctica, Aquat. Geochem., 10, 199-220, 2004.

Mindl, B., Anesio, A. M., Meirer, K., Hodson, A. J., LaybournParry, J., Sommaruga, R., and Sattler, B.: Factors influencing bacterial dynamics along a transect from supraglacial runoff to proglacial lakes of a high Arctic glacier, FEMS Microbiol. Ecol., 59, 307-317, 2007.

Murphy, J. and Riley, J. P.: A modified single solution method for determination of phosphate in natural waters, Anal. Chim. Acta, 26, 31-36, 1962.

Nedoma, J., Štrojsová, A., Vrba, J., Komárková, J., and Šimek, K.: Extracellular phosphatase activity of natural plankton studied with ELF97 phosphate: fluorescence quantification and labelling kinetics, Environ. Microbiol., 5, 462-472, 2003.

Pettersson, K.: Alkaline phosphatase activity and algal surplus phosphorus as phosphorus-deficiency indicators in Lake Erken, Arch. Hydrobiol., 89, 54-87, 1980.

Price, N. M. and Morel, F. M. M.: Role of extracellular enzymatic reactions in natural waters, in: Aquatic Chemical Kinetics: Reaction Rates of Processes in Natural Waters, edited by: Stumm, W., Wiley, New York, 235-257, 1990.

Säwström, C., Mumford, P., Marshall, W., Hodson, A., and Laybourn-Parry, J.: The microbial communities and primary productivity of cryoconite holes in Arctic glacier (Svalbard $79^{\circ} \mathrm{N}$ ), Polar Biol., 25, 591-596, 2002.

Säwström, C., Laybourn-Parry, J., Granéli, W., and Anesio, A. M.: Heterotrophic bacterial and viral dynamics in Arctic freshwaters: results from a field study and nutrient-temperature manipulation experiments, Polar Biol., 30, 1407-1415, 2007.

Sirová, D., Vrba, J., and Rejmánková, E.: Extracellular enzyme 
activities in benthic cyanobacterial mats: comparison between nutrient-enriched and control sites in marshes of northern Belize, Aquat. Microb. Ecol., 44, 11-20, 2006.

Stibal, M., Šabacká, M., and Kaštovská, K.: Microbial communities on glacier surfaces in Svalbard: impact of physical and chemical properties on abundance and structure of cyanobacteria and algae, Microb. Ecol., 52, 644-654, 2006.

Stibal, M., Elster, J., Šabacká, M., and Kaštovská, K.: Seasonal and diel changes in photosynthetic activity of the snow alga Chlamydomonas nivalis (Chlorophyceae) from Svalbard determined by pulse amplitude modulation fluorometry, FEMS Microbiol. Ecol., 59, 265-273, 2007.
Stibal, M. and Tranter, M.: Laboratory investigation of inorganic carbon uptake by cryoconite debris from Werenskioldbreen, Svalbard, J. Geophys. Res., 112, G04S33, doi:10.1029/2007JG000429, 2007.

Stibal, M., Tranter, M., Benning, L. G., and Řehák, J.: Microbial primary production on an Arctic glacier is insignificant in comparison with allochthonous organic carbon input, Environ. Microbiol., 10, 2172-2178, 2008a.

Stibal, M., Tranter, M., Telling, J., and Benning, L. G.: Speciation, phase association and potential bioavailability of phosphorus on a Svalbard glacier, Biogeochemistry, 90, 1-13, 2008b.

Wharton Jr., R. A., McKay, C. P., Simmons Jr., G. M., and Parker, B. C.: Cryoconite holes on glaciers, BioScience, 35, 499-503, 1985. 